\title{
The Problems of Digital Da'wah during the Covid-19 Pandemic
}

\author{
Tri Ermayani ${ }^{1}$, Rofiq Nurhadi ${ }^{2}$, Edi Sunjayanto Masykuri ${ }^{3}$ \\ \{esunjayanto@gmail.com ${ }^{3}$ \} \\ Faculty of Teacher Training and Education, Muhammadiyah Purworejo University, Indonesia ${ }^{1,2,3}$
}

\begin{abstract}
Currently the world is in crisis due to the emergence of Covid-19 and it has an impact on the lives of all sectors of people's lives. Da'wah is an urgent problem because it involves the human need for life motivation to increase individual religiosity as religious beings in the midst of life difficulties due to the impact of Covid-19. Da'wah always has opportunities and challenges in its implementation to determine plans and strategies. Da'wah is a need of everyone, especially Muslims, so that the preachers use various ways to convey the message of da'wah. In real life, the implementation of da'wah using online or digital media has been going on for a long time, but over time in Covid-19 the amount of use of digital media has become very dominant. Research on digital da'wah problems in the Covid-19 era, researchers used qualitative descriptive methods to collect problems in the application of digital da'wah in the Covid-19 period. The problem of digital da'wah includes several things, including the capacity and capability of preachers, the physical and social environment, the level of education, da'wah strategies, community responses, and da'wah media. Through this research, an important solution was found to solve the problem of digital da'wah in the Covid19 pandemic, namely digital training for preaching, preaching motivation, the use of multi-purpose da'wah, awareness of parents and educators to play a role in Islamic da'wah.
\end{abstract}

Keywords: Digital da'wah, Pandemic covid-19, Media da'wah

\section{Introduction}

The world of communication today is faced new era, especially in Indonesia. It is technology and communication developments which has multi-effects for community due to information sharing. There is communication mass media plays a function to convey messages easily to public [1]. It is a new media to encompass digital emergence, computers, or information and communication technology networks in the late 20th century. Most of the technologies described as new media are digital, often has the characteristics of being manipulative, networked, compact, incompressible, interactive and not taking sides [2]. In simple way, new media defines media technology communication involving the computer in it both based on PC and notebook. It will form an interaction between humans and computers and the internet in particular, including to; web, blog, online social network, online forum and others that use computer as the media [3]. In the same time, it can be found in a network by clicking the mouse, or even just download the database our electronics simply [4].

Da'wah tries to guide its people in order religious awareness grows in carrying out religious teachings in a wiser way so as to make an impact constructive for the life of the wider 
community. Included in this is to use media. Da'wah by technology needs not only spiritual development but also needs its existence as a consequence of modernization of the times. Phenomenon da'wah through social media; facebook, Instagram, podcast, blog and youtube is one part of communication and Islamic broadcasting. Community needs to fulfill aspects of various method-related innovation of da'wah [5]. Yet digital da'wah meets some challenges; content, innovation and attitude. Yet, we have a problem in content. Too many contents sometimes do not solve the problem. It has a vagueness of its essence and purpose. It is interference of such materialism, hedonism, and capitalism of course those will be a threat to the existence of fundamental value of da'wah [5]. The amount of public interest in digital media is not as equal as the high expectations of da'wah because of less innovation then it influences the user of da'wah itself [6]. The last is the attitude, the modern era born dynamic Muslim society. It means in society, there are many different thought and perspectives. The tendency becomes one of the determining factors for the success of preaching goals [5] [7].

In the previous study, the researchers have observed the new concept of da'wah, the comparison and its impact [5]. Da'wah is not only about communication but also participation between da'i to jama'ah. It means there is interaction among them [8], strategy to touch both psychology and sociological aspect which considered in carrying out the situation and the condition of the target of preaching [9], for example, local government politics, the majority of religions in an area, philosophical preaching targets, and socio-cultural targets of da'wah. The study of good communication between different perspectives; the puritan and traditional using a symbol [10], communication by social participation [11], strategy to prepare new da'i with digitalization [12][13].

Regarding to the latest condition, there are three problem statements in da'wah concept, they are:

- Why and how does the da'wah transform into digital communication?

- What are digital da'wah challenges in the pandemic era?

- How digital da'wah can be acceptable in some communities?

\section{Methods}

This research is descriptive, qualitative research approach tringulation data collection, the object of this research is the internet media then interpreted as part of a new media towards the expression of the diversity of ddai and the ummat, or anything related to $d a$ 'wah in new media. This research is more concerned with what rather than how or why something has happened [14]. Therefore, observation and survey tools are often used to gather data Approach This research is called a qualitative descriptive approach. The reason researchers use Qualitative method approaches include researchers who already know existing conditions in new media. And this adds to the resilience of researchers make it easier to do research with this type of qualitative research or research which in it prioritizes an analysis of an event or the process as it is in a natural environment to acquire meaning of the essence of the process [15].

\section{Results and Discussion}

The communication media is important for $d a$ ' $i$ to convey the message persuading people to stay in his/her religion. It is called $d a$ 'wah. The transformation of $d a$ 'wah is growing fast in 
the pandemic Covid 9 besides Industrial revolution 4.0 era. The communication uses from one to another; the traditional to digital tools [16]. The new da'wah used digital became more popular. According to the media, the digital $d a$ 'wah is divided on three; audio, visual and audio visual.

\subsection{Digital $d a$ 'wah by audio}

This communication uses audio for the media. The $d a$ ' $i$ converted the materials to MP3 through application in smartphone, which people use in his/her daily life. It has many kind of application (apps); They are Anchor apps, Spotify apps, podcast apps, google podcast apps and so on, we can find digital online podcast or fm radio, such as Bahasa Arab on Spotify (https://open.spotify.com/episode/1x3NdZ6wP6zZKoZniL8LL1) show in Figure 1 and podcast inspirasi Nabi by Muda Community (https://anchor.fm/mudacommunity) show in Figure 2. The contain of the da'wah is most about history of Prophet Muhammad, learning Arabic; tahsin and tajwid, social life (muamallah) and so on. The duration can take long one; 5-160 minutes.

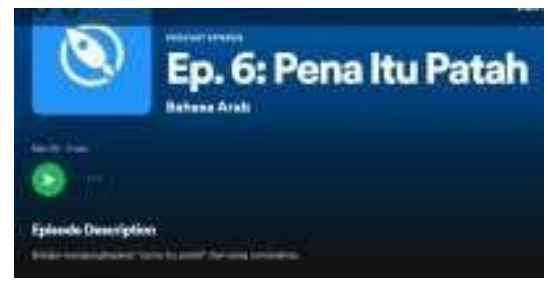

Fig. 1. Spotify

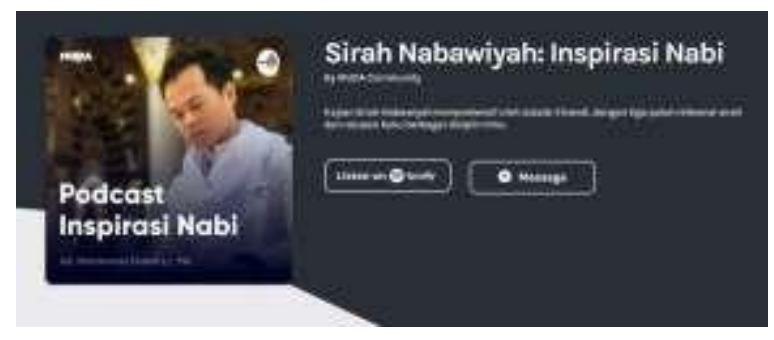

Fig. 2. Anchor

\subsection{Digital $d a$ 'wah by visuality}

This communication uses visulality only for the media. They use picture, meme or just a text. In picture we can find it in graphic design on pinterest (https://pin.it/1azeifv) show in Figure 3), blog (https://umma.id/post/aku-istihadhah-atau-haid-sih-361988?lang=id) show in Figure 4, and so on. The content of the da'wah is almost about figh; tips to do something correctly as muslim, such as how to use male or female perfume, how to pray correctly and so on. 


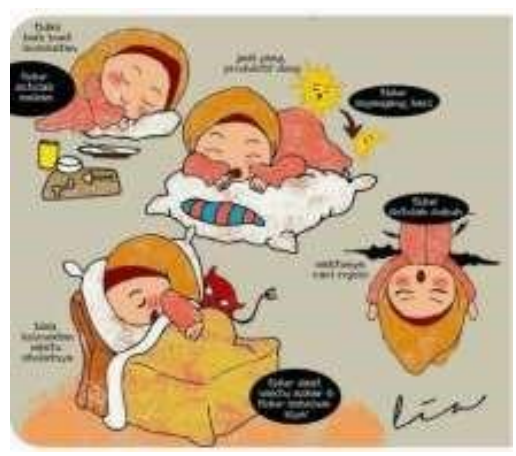

Fig. 3. Pinterest

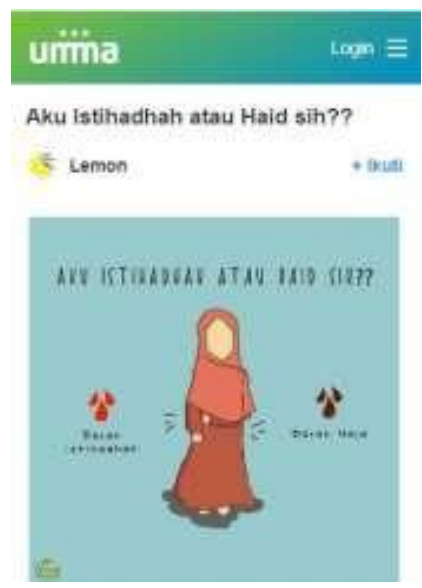

Fig. 4. Blog

\subsubsection{Digital $d a^{\prime}$ wah with audio and visual}

This communication uses audio and visual for the media, there are shown mostly in MP4. The media will be put in Instagram (Figure 5), facebook (Figure 6), youtube (Figure 7), and zoom (Figure 8). The contents are about aqidah, fiqh, muamallah, siroh nabawiyah, tajwid, tahsin, shorf and so on. It is more popular than digital visual and audio because the users can watch some moving pictures.

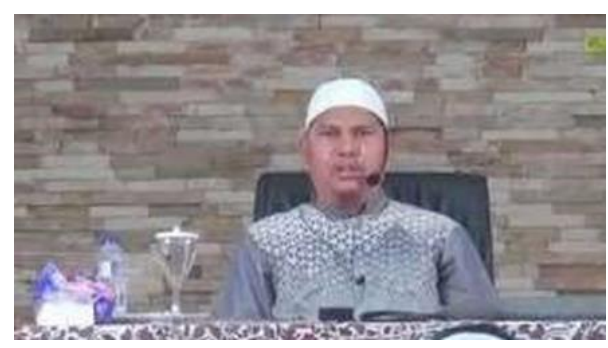


Fig. 5. Instagram

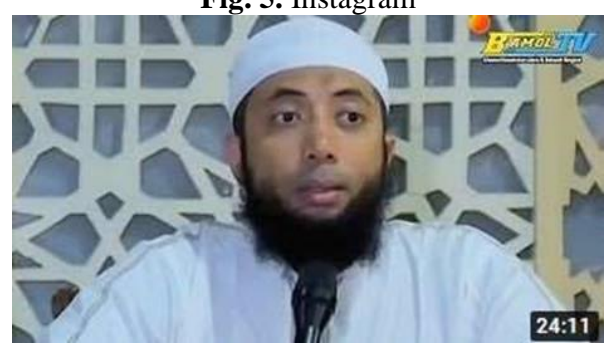

Fig. 6. Facebook

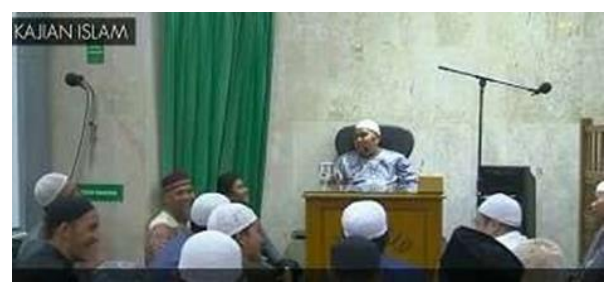

Fig. 7. Youtube

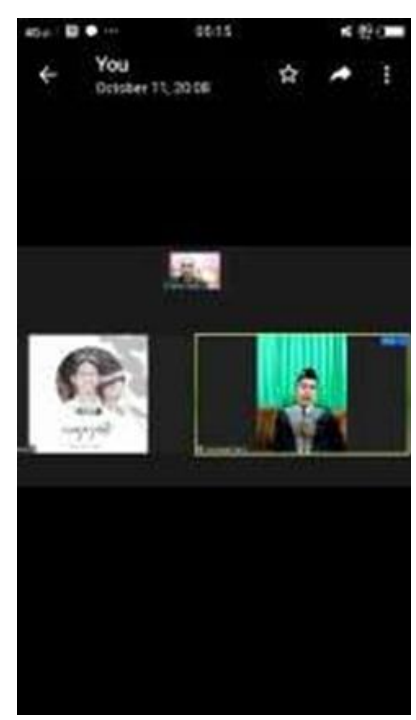

Fig. 8. Zoom

This digital with audio and visual has many varied options in content. It is also popular in the youth because of simple and downloadable. But sometimes it is found some problems; the channels are so many that those are not viewed because less of quality or same content. The $d a$ ' $i$ just want jamaah to click like and subscribe. It means that $d a^{\prime} i$ has another intention in making his/her channels. The channel has a limited- duration; 5-30 minutes. 


\subsection{Discussion}

Digital da'wah has some problems; the personal digital ability. It is not easy to transform the class in the pedagogic perspective. $D a$ ' $i$ should schedule for the virtual classroom as he/she wishes, and aware the interesting one to stimulate jama'ah to learn and participate in virtual class activity. In reality, the learners do not seem to consider it as a real classroom or real rubric, and $d a$ ' $i$ did not have a control the virtual class. Another problem is too many channels in different platform, yet it has the same content. The audience can be confused and they just choose the favorite or popular $d a^{\prime} i$. It makes the messages have not conveyed maximally. Therefore $d a$ ' $i$ meets two challenges; how to master digital communication, make content with good quality in audio and visual, and set a virtual classroom by digital platform, like facebook, Instagram, youtube etc. The second is how to focus on certain topic and level. It will make sure the audiences understand and messages are transferred well.

\section{Conclusion}

All thing removed the manual way to digital. They are included on market, education, security, and so on. It is involved on communication. Da'wah is how to persuade someone or people to do better in relationship between God and human and human to social according to Islam direction. Da'wah is one of the communication systems which transforms into digital communication through audio, visual or audio visual. Recently people know the facebook, Instagram, youtube, and podcast o her/his smartphone. They are so popular in all generations.

\section{Acknowledgment}

We would like to express my big thanks to Allah Subhanahu Wa Ta'ala, The Almighty. We can finish our article soon. Our best friends in University, motivates and burns our spirit. My beloved friend as researchers who give us support financially also aided us in holding and focusing the research and we know so many new things we are thankful to them. Secondly, we would like to thank friends and participants who give much help to us in completing this project in the limited time.

\section{References}

[1] Lilweri, Memahami peran Komunikasi Massa dalam Masyarakat. Bandung: Citra Aditya Bakti, 1991.

[2] Asmar, "Ekspresi Keberagaman Online: Media Baru Dan Dakwah," Jurnal Ilmu Dakwah, vol. 40, $\begin{array}{lccc}\text { no. } & 1, & \text { 2020, } & \text { [Online]. } \\ \text { https://journal.walisongo.ac.id/index.php/dakwah/article/view/5298/2752. }\end{array}$

[3] R. K. Logan, Understanding New Media. New York: Peter Lang, 2010. [4] On Religion. London. UK: Roudlege, 2001.

[4] N. Ahmad, "Rekonstruksi Dakwahtainment Sebagai Media Dakwah,” Jurnal Dakwah, vol. 19, no. 2, 2018, [Online]. Available: http://ejournal.uinsuka.ac.id/dakwah/jurnaldakwah/article/view/1374/1124. 
[5] Juniawati, "Dakwah Melalui Media Elektronik: Peran dan Potensi Media Elektronik dalam Dakwah Islam di Kalimantan Barat," Jurnal Dakwah, vol. 15, no. 2, 2014, [Online]. Available: http://ejournal.uinsuka.ac.id/dakwah/jurnaldakwah/article/view/305/284.

[6] Sudirman, "Persaudaraan Islam sebagai Pondasi Terwujudnya Organisasi yang mandiri dan Profesional," Jurnal Pendidikan Islam, vol. 14, no. 1, 2016.

[7] M. W. Hasyim, "Dakwah Bertingkat Majalah Suara Mihammadiyah," Jurnal Dakwah, vol. 9, no. 1, 2008, [Online]. Available: http://ejournal.uin-suka.ac.id/dakwah/jurnaldakwah/article/view/438/407.

[8] R. Mahri, "DAKWAH KAMPUS BERBASIS RISET," Jurnal Dakwah, vol. 14, no. 1, 2013, [Online]. Available: http://ejournal.uinsuka.ac.id/dakwah/jurnaldakwah/article/view/275/255.

[9] R. Nurhadi and E. S. Masykuri, "Symbol Meaning and Dialectic Perspectives on Social Media," presented at the Proceedings of the 1st Borobudur International Symposium on Humanities, Economics and Social Sciences (BIS-HESS 2019), Magelang, Indonesia, May 2020, doi: https://doi.org/10.2991/assehr.k.200529.234. [11] E. Sunjayanto Masykuri and et all, "Integrated Technology And Mutual Participation For Changing Communities Socially, Economically And Religiously," presented at the ICSTI, Indonesia, Oct. 2018, [Online]. Available: https://eudl.eu/doi/10.4108/eai.19-10-2018.2281307.

[10] M. Alwi, "Gerakan Dakwah Muhammadiyah di Sulawesi Selatan,” Jurnal Diskursus Islam, vol. 1, no. 1, Apr. 2013.

[11] F. Fachrul Kurniawan, "Pemanfaatan Langsung Teknologi Informasi Dalam Dakwah Islam," Ulul Albab, vol. 13, no. 1, 2012, doi: 10.18860/ua.v0i0.2379.

[12] W. R. Borg and Gall, M. D., Educational Research An Introduction. London: Longman, 1983.

[13] Subaidi, "Pati Dan Silahul Ulum Asempapan Trangkil Pati.," Jurnal Pendidikan Islam, vol. 2, no. 1, pp. 71-72, 2019.

[14] S. Yue Hua Sun, "Online Language Teaching: the Pedagogical Challenges," Knowledge Management \& E-Learning: An International Journal, vol. 3, no. 3, 2011. 